\title{
A cost-utility analysis of nursing intervention via telephone follow-up for injured road users Carin Franzén*1,2, Ulf Björnstig ${ }^{3}$, Christine Brulin ${ }^{4}$ and Lars Lindholm ${ }^{5}$
}

Address: ${ }^{1}$ Department of Nursing, Division of Surgery, Umeå University, S-901 87 Umeå, Sweden, ${ }^{2}$ Department of Surgical and Perioperative Sciences, Division of Surgery, Umeå University, S-901 87 Umeå, Sweden, ${ }^{3}$ Department of Surgical and Perioperative Sciences, Division of Surgery, Umeå University, S-901 87 Umeå, Sweden, ${ }^{4}$ Department of Nursing, Umeå University, SE-901 87 Umeå, Sweden and ${ }^{5}$ Department of Public Health and Clinical Medicine, Umeå University, 90187 Umeå, Sweden

Email: Carin Franzén* - carin.franzen@nurs.umu.se; Ulf Björnstig - ulf.bjornstig@vll.se; Christine Brulin - christine.brulin@nurs.umu.se; Lars Lindholm - lars.lindholm@epiph.umu.se

* Corresponding author

Published: II June 2009

BMC Health Services Research 2009, 9:98 doi:10.1186/1472-6963-9-98
Received: II June 2008

Accepted: II June 2009

This article is available from: http://www.biomedcentral.com/I472-6963/9/98

(c) 2009 Franzén et al; licensee BioMed Central Ltd.

This is an Open Access article distributed under the terms of the Creative Commons Attribution License (http://creativecommons.org/licenses/by/2.0), which permits unrestricted use, distribution, and reproduction in any medium, provided the original work is properly cited.

\begin{abstract}
Background: Traffic injuries can cause physical, psychological, and economical impairment, and affected individuals may also experience shortcomings in their post-accident care and treatment. In an earlier randomised controlled study of nursing intervention via telephone follow-up, self-ratings of health-related quality of life were generally higher in the intervention group than in the control group.
\end{abstract}

Objective: To evaluate the cost-effectiveness of nursing intervention via telephone follow-up by examining costs and quality-adjusted life years (QALYs).

Methods: A randomised controlled study was conducted between April 2003 and April 2005. Car occupants, cyclists, and pedestrians aged between 18 and 70 years and attending the Emergency Department of Umeå University Hospital in Sweden after an injury event in the traffic environment were randomly assigned to an intervention $(n=288)$ or control group $(n=280)$. The intervention group received routine care supplemented by nursing via telephone follow-up during half a year, while the control group received routine care only. Data were collected from a mail survey using the non-disease-specific health-related quality of life instrument EQ5D, and a cost-effectiveness analysis was performed including the costs of the intervention and the QALYs gained.

Results: Overall, the intervention group gained 2.60 QALYs (260 individuals with an average gain of 0.0 I QALYs). The car occupants gained I.54 QALYs (76 individuals, average of 0.02 ). Thus, the cost per QALY gained was 16000 Swedish Crown (SEK) overall and 8500 SEK for car occupants.

Conclusion: Nursing intervention by telephone follow-up after an injury event, is a cost effective method giving improved QALY to a very low cost, especially for those with minor injuries.

Trial registration: This trial registration number is: ISRCTNII 746866. 


\section{Background}

Road traffic injuries are a major global problem. The World Health Organisation (WHO) currently ranks traffic crashes as the ninth leading cause of disability, and it has been estimated that by 2020 they will have risen to third place, behind heart disease and depression [1]. In Sweden, 1.4 per 100 inhabitants are injured in the traffic environment each year [2]; the three most frequently injured categories are car occupants, cyclists, and pedestrians, injured for example by falls (Swedish Institute for Transport and Communication Analysis, SIKA 2006:31). The economic cost of road crashes and injuries is enormous. The global cost is conservatively estimated to be between $1 \%$ and $2 \%$ of gross national product [3]. In addition, earlier studies have also shown QALY losses after injury events in the traffic environment $[4,5]$. In a study of the value of a statistical life in the road traffic sector, Persson et al. [6] estimated the value of a statistical life in 1999 prices at 20 million Swedish crown (SEK), that of a severe casualty at 3.3 million SEK, and that of a minor casualty at about 0.3 million SEK.

Since traffic injuries are an increasing global problem, it is important not only to prevent injuries but also to provide proper care and treatment to the injured persons. Earlier studies have indicated shortcomings in treatment, care and rehabilitation after an injury event. For example, Franzén et al. [7] pointed out that persons with nonminor injuries rated their quality of care in the emergency department after injury event higher than those with minor injuries, even if the importance for quality of care was the same for both groups. Furthermore, Cedergren \& Bylund [8] and Albertsson \& Björnstig [9] showed that injured people lacked both support and information from their caregivers during a hospital stay, and were also uncertain of where to go for help with any further needs after discharge. Moreover, Franzén et al. [10] showed that lack of information from caregivers created perceived feelings of anxiety and uncertainty among the injured. In addition, several studies has indicated that an awareness of those injured persons who need more extensive support is important for both quality of care and healthrelated quality of life [11-13]. A number of authors have also pointed out the need for more effective interventions after an injury event [14-17]. Nursing intervention by telephone follow-up (TFU) could offer one way to provide such intervention.

In an earlier randomised controlled intervention study [18] we investigated three road user categories (car occupants, cyclists, and pedestrians) who attended the Emergency Department of Umeå University Hospital in northern Sweden. Both groups received routine care according to current standard trauma principles, ATLS [19] and TNCC [20], and the intervention group also received nursing intervention by TFU after discharge from the hospital. The intervention calls lasted an average of 20 minutes ( $\mathrm{SD}=9.56)$, and $62 \%$ needed specific intervention advice. Patients' concerns were classified into six major areas and ranked according to frequency. The six areas were: self-care (29\%), recommendation to seek further medical attention at the local hospital's medical centre $(26 \%)$, explanation of symptoms (25\%), recommendation to seek a physiotherapist $(11 \%)$, information on prognosis $(5 \%)$, and pharmacological information (4\%). The main results from the study showed that, in general, the intervention group rated their healthrelated quality of life significantly higher than did the control group. This improvement was most pronounced in the group of those provided with advice as part of TFU. The car occupants gained most advantage from the TFU, with significantly lower problems in the dimensions of pain/discomfort and usual activities.

Earlier economic studies including TFU as a part of the intervention have been conducted for various patient categories, mainly in the context of cardiac rehabilitation [21-23], antibiotic prescriptions [24], early obstetrical discharge [25], depression [26], telephone triage in general practice [27], telephone triage for asthma [28], telephone triage for patients in the National Health Service [29], and advice on newly prescribed medicines [30]. These studies showed that while these interventions are generally less costly, except in a couple of cases $[29,30]$ they are also ineffective. However, our TFU study showed significant higher QALY scores in the intervention group than in the control group (Table 1). In an environment where health care resources are scarce, it is important not only to show that a follow-up method is effective, but also to demonstrate that it offers value for money. Nevertheless, to our knowledge, the cost-utility of nursing intervention via TFU after an injury event in the traffic environment has not yet been clarified.

The aim of the present study was to evaluate the cost-effectiveness of nursing intervention via telephone follow-up by examining costs and quality-adjusted life years.

\section{Methods \\ Selection procedure}

A randomised controlled trial design was used. Data were collected from April 2003 to April 2005. Firstly, a stratified consecutive sample procedure was used to select a representative sample of participants from three different road user categories: car occupants, cyclists, and pedestrians (falls, non-vehicle injuries). Secondly, a randomised procedure was used to allocate each patient to either the intervention or the control group. The sample size was determined by power analysis based on a significance level of 0.05 and power $=0.90$. A total of 300 participants 
Table I: Mean of EQ-5D index for the responders at baseline in the intervention group $(n=288)$ and control group $(n=280)$ and after 6 months in the intervention group $(n=260)$ and control group $(n=250)$.

\begin{tabular}{|c|c|c|c|}
\hline \multicolumn{4}{|c|}{ EQ-5D Index } \\
\hline & $\begin{array}{l}\text { EQ-5D } \\
\text { Baseline }\end{array}$ & $\begin{array}{l}\text { EQ-5D } \\
3 \text { months }\end{array}$ & $\begin{array}{l}\text { EQ-5D } \\
6 \text { months }\end{array}$ \\
\hline Groups & Mean (SD) & Mean (SD) & Mean (SD) Confidence interval (Cl) \\
\hline Intervention group & $0.64(0.31)$ & $0.80(0.22)$ & $0.85(0.20) 0.8209-0.8698$ \\
\hline Control group & $0.64(0.3 \mathrm{I})$ & & $0.81(0.21) 0.7842-0.8359$ \\
\hline P-value & 0.92 & & 0.05 \\
\hline Intervention car occupants & $0.71(0.28)$ & $0.81(0.23)$ & $0.87(0.18) 0.8323-0.9141$ \\
\hline Control car occupants & $0.680 .32)$ & & $0.79(0.21) 0.7406-0.8402$ \\
\hline P-value & 0.44 & & 0.01 \\
\hline Intervention cyclists & $0.66(0.30)$ & $0.84(0.21)$ & $0.86(0.21)$ \\
\hline Control cyclists & $0.68(0.28)$ & & $0.86(0.17)$ \\
\hline P-value & 0.60 & & 0.92 \\
\hline Intervention pedestrians & $0.55(0.32)$ & $0.75(0.20)$ & $0.8 \mathrm{I}(0.20)$ \\
\hline Control pedestrians & $0.57(0.32)$ & & $0.78(0.24)$ \\
\hline P-value & 0.72 & & 0.29 \\
\hline
\end{tabular}

in each group were necessary to find a difference of 0.03 in the EQ-5D index, and similarly for subgroups of size 150 participants in each group a difference of 0.05 were adequate.

Detailed descriptions of the selection procedure for the intervention and the control group and the data collection procedure are given in Figure 1.

\section{Participants}

The inclusion criteria in this study were: (1) age between 18 and 70 years; (2) being; (i) car occupant, (ii) cyclist, or (iii) pedestrian; and (3) having attended the Emergency Department of Umeå University Hospital in northern Sweden after an injury event in the traffic environment. Participants were excluded if they were diagnosed with dementia or mental illness. The injuries were classified according to the Abbreviated Injury Scale (AIS), where MAIS denotes the Maximum AIS. AIS $=1$ is a minor injury (e.g. whiplash injury, sprain, finger fracture), AIS $=2$ is a moderate injury (e.g. concussion, radius fracture), AIS = 3 is a serious injury (femoral fracture, intra-abdominal bleeding), and the scale continues up to AIS $=6$, which covers fatal injuries [31]

In our results, we present two injury groups; those with minor injuries (MAIS $=1$ ) and those with moderate and more serious injuries (MAIS $=2+$ ). Following the power calculation, a total of 920 individuals were invited to participate; 568 of them accepted the invitation. Background characteristics for the responders in the intervention group and control group are shown in Table 2. Participants and refusals differed in that there were more males among the refusals (59\%) than among the participants $(38 \%)$, and there were also more MAIS 1 injuries among the refusals (77\% vs. 63\%). The refusals were also slightly younger, with a mean age of 36.8 (SD: 13.6) as compared to 43.8 (SD: 15.1 ) years.

\section{Procedure}

A letter with information about the study and an invitation to participate was sent to the invited participants in both the intervention and the control group about three weeks after the injury event. Informed consent was given 


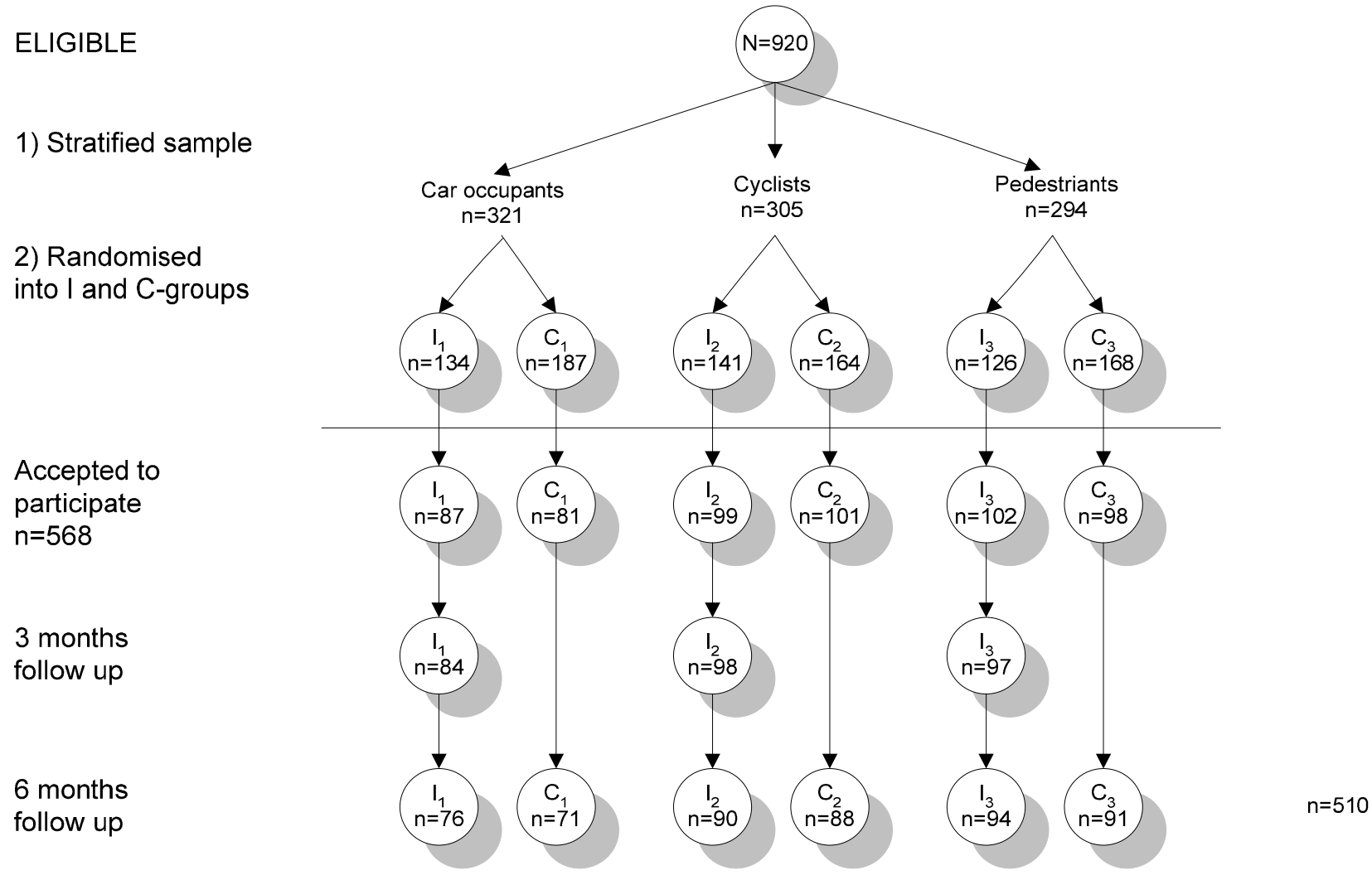

Figure I

Selection and data collection procedure for the intervention and control groups. $* I=$ Intervention group. $* C=$ Control group.

written from the participants. In order to evaluate the intervention, the EQ-5D questionnaire was sent twice, first with the invitation letter and again after six months. The intervention group also received a questionnaire after three months.

EQ-5D is a non-disease-specific self-report instrument for measuring health-related quality of life. It consists of the EQ-5D self-classifier and the EQ visual analogue scale [32]. Respondents are asked to classify their own health status in five dimensions: mobility, self-care, usual activities, pain/discomfort, and anxiety/depression. Answers are given on a three point scale: $1=$ no problems, $2=$ moderate problems, and $3=$ severe problems. Theoretically, 243 health statuses could be generated by this classification. Each health status can be given a value from -0.59 to 1.0 by means of the time-trade method (Dolan 1997).

For the economic analysis in the present study, the EQ-5D index values were used to calculate health gains in QALYs $[33,34]$. The QALY is an approximation of utility; it com- bines the time spent in a health state with the quality experienced during that time $[35,36]$.

All costs presented are mean costs evaluated in 2008 SEK (Table 3). Health care costs include the cost of nursing time, which was based on mean wages for registered nurses. We have used the market decided wages for nurses, and we got the information from the administration of the Västerbotten county council in Sweden. The meanwage was 33778 SEK per month and 211 SEK per hour. The clinic used in the trial is situated at the university, so telephone costs and overhead costs were obtained from the university department. The time spent on each telephone call was recorded, as was any time needed for preparation (reading medical records) and supplementary work (making notes after the telephone call).

\section{Statistical analysis}

The intervention and control group and their subgroups were compared with respect to the following background characteristics: MAIS, sex, marital status, education, and 
Table 2: Background characteristics for the responders in the intervention group $(n=288)$ and the control group $(n=280)$.

Car occupants Car occupants P-value Cyclists Cyclists P-value Pedestrians

$(n=87) \quad(n=81)$

$(n=101)$

$(n=102)$

Pedestrian
$(n=98)$

Total P-value

(n)

$(\mathrm{n}=81)$

\begin{tabular}{|c|c|c|c|c|c|c|c|c|c|c|c|c|}
\hline & Intervention & Control & & Intervention & Control & & Intervention & Control & & Intervention & Control & \\
\hline Age & $\begin{array}{l}38.47 \\
(12.02)\end{array}$ & $\begin{array}{l}38.63 \\
(13.98)\end{array}$ & 0.938 & $\begin{array}{l}42.28 \\
(15.33)\end{array}$ & $\begin{array}{l}39.71 \\
(15.38)\end{array}$ & 0.238 & $\begin{array}{l}51.00 \\
(13.00)\end{array}$ & $\begin{array}{l}51.29 \\
(14.52)\end{array}$ & 0.880 & $\begin{array}{l}44.22 \\
(14.5 \mathrm{I})\end{array}$ & $\begin{array}{l}43.25 \\
(15.73)\end{array}$ & 0.547 \\
\hline
\end{tabular}

\section{MAIS}

\begin{tabular}{|c|c|c|c|c|c|c|c|c|c|c|c|c|}
\hline I & $\begin{array}{l}79 \\
(91 \%)\end{array}$ & $\begin{array}{l}73 \\
(90 \%)\end{array}$ & 0.580 & $\begin{array}{l}58 \\
(59 \%)\end{array}$ & $\begin{array}{l}58 \\
(57 \%)\end{array}$ & 0.984 & $\begin{array}{l}47 \\
(46 \%)\end{array}$ & $\begin{array}{l}43 \\
(44 \%)\end{array}$ & 0.552 & $\begin{array}{l}184 \\
(64 \%)\end{array}$ & $\begin{array}{l}174 \\
(62 \%)\end{array}$ & 0.823 \\
\hline $2+$ & $\begin{array}{l}8 \\
(9 \%)\end{array}$ & $\begin{array}{l}8 \\
(10 \%)\end{array}$ & & $\begin{array}{l}41 \\
(41 \%)\end{array}$ & $\begin{array}{l}43 \\
(43 \%)\end{array}$ & & $\begin{array}{l}55 \\
(54 \%)\end{array}$ & $\begin{array}{l}55 \\
(56 \%)\end{array}$ & & $\begin{array}{l}104 \\
(36 \%)\end{array}$ & $\begin{array}{l}106 \\
(38 \%)\end{array}$ & \\
\hline
\end{tabular}

Sex

\begin{tabular}{|c|c|c|c|c|c|c|c|c|c|c|c|c|}
\hline Male & $\begin{array}{l}47 \\
(54 \%)\end{array}$ & $\begin{array}{l}35 \\
(43 \%)\end{array}$ & 0.211 & $\begin{array}{l}33 \\
(33 \%)\end{array}$ & $\begin{array}{l}49 \\
(49 \%)\end{array}$ & 0.029 & $\begin{array}{l}26 \\
(25 \%)\end{array}$ & $\begin{array}{l}26 \\
(27 \%)\end{array}$ & 0.964 & $\begin{array}{l}106 \\
(37 \%)\end{array}$ & $\begin{array}{l}110 \\
(39 \%)\end{array}$ & 0.533 \\
\hline Female & $\begin{array}{l}40 \\
(46 \%)\end{array}$ & $\begin{array}{l}46 \\
(57 \%)\end{array}$ & & $\begin{array}{l}66 \\
(67 \%)\end{array}$ & $\begin{array}{l}52 \\
(51 \%)\end{array}$ & & $\begin{array}{l}76 \\
(75 \%)\end{array}$ & $\begin{array}{l}72 \\
(73 \%)\end{array}$ & & $\begin{array}{l}182 \\
(63 \%)\end{array}$ & $\begin{array}{l}170 \\
(61 \%)\end{array}$ & \\
\hline
\end{tabular}

Marital status 
Table 2: Background characteristics for the responders in the intervention group $(n=288)$ and the control group $(n=280)$. (Continued)

Not single

$72 \quad 65$

65
$(80 \%)$

0.14268

70

0.753

$\begin{array}{ll}87 & 67 \\ (85 \%) & (69 \%)\end{array}$

0.062

228

202

0.094

Single

$15 \quad 16$

16
$(20 \%)$

\begin{tabular}{ll}
\hline 31 & 31 \\
$(30 \%)$ & $(31 \%)$
\end{tabular}

\begin{tabular}{ll}
\hline 15 & 31 \\
$(15 \%)$ & $(32 \%)$
\end{tabular}

\section{0}

$60 \quad 78$

\section{Education level}

Less than high school 9 11 15 13

$37 \quad 30$

30

61
54

\begin{tabular}{lll}
\hline High school & $\begin{array}{l}44 \\
(51 \%)\end{array}$ & $\begin{array}{l}42 \\
(52 \%)\end{array}$ \\
& & \\
\hline University & 34 & 28 \\
& $(39 \%)$ & $(34 \%)$
\end{tabular}

0.696

$38 \quad 36$

$36 \quad 0.762$

33

37

(33\%) $\quad 37$

\begin{tabular}{ll}
\hline 46 & 52 \\
$(47 \%)$ & $(51 \%)$
\end{tabular}

\begin{tabular}{ll}
\hline 32 & 31 \\
$(31 \%)$ & $(32 \%)$
\end{tabular}

31
$(32 \%)$

0.686

\begin{tabular}{ll}
115 & 115 \\
$(40 \%)$ & $(41 \%)$ \\
\hline 112 & 111 \\
$(39 \%)$ & $(39 \%)$
\end{tabular}

\section{Work}

Employment

$66 \quad 65$

65
$(81 \%)$

$0.294 \quad 62$

$62 \quad 69$

69
$(68 \%)$

$\mathbf{0 . 4 5 0}$

$74 \quad 62 \%$

$62 \%$

(64\%)

0.259

202
$(70 \%)$

202
$(70 \%)$

196

196
$(70 \%)$

0.108

\begin{tabular}{|c|c|c|}
\hline $\begin{array}{l}\text { Retired to some } \\
\text { extent }\end{array}$ & $\begin{array}{l}9 \\
(10 \%)\end{array}$ & $\begin{array}{l}6 \\
(7 \%)\end{array}$ \\
\hline Student & $\begin{array}{l}8 \\
(9 \%)\end{array}$ & $\begin{array}{l}6 \\
(7 \%)\end{array}$ \\
\hline Unemployed & $\begin{array}{l}4 \\
(5 \%)\end{array}$ & $\begin{array}{l}4 \\
(5 \%)\end{array}$ \\
\hline
\end{tabular}

\begin{tabular}{ll}
\hline 12 & 8 \\
$(12 \%)$ & $(8 \%)$ \\
\hline 20 & 21 \\
$(20 \%)$ & $(21 \%)$ \\
\hline 5 & 3 \\
\hline$(5 \%)$ & $(3 \%)$
\end{tabular}

\begin{tabular}{ll}
\hline $\begin{array}{l}21 \\
(21 \%)\end{array}$ & $\begin{array}{l}25 \\
(25 \%)\end{array}$ \\
\hline 3 & 10 \\
$(3 \%)$ & $(10 \%)$ \\
\hline 4 & 1 \\
$(4 \%)$ & $(1 \%)$
\end{tabular}

\begin{tabular}{ll}
\hline 42 & $(39$ \\
$(15 \%)$ & $(14 \%)$ \\
\hline 31 & 37 \\
$(11 \%)$ & $(13 \%)$ \\
\hline 13 & 8 \\
$(4 \%)$ & $(3 \%)$
\end{tabular}


employment. Chi2 test was used and for age independent t-test. The outcome variable was self-rated health expressed as mean QALY score on the UK EQ-5D index tariff [37] and was analysed with independent $t$-test. All analysis was performed using SPSS version 13, with significance level set at $\mathrm{p} \leq 0.05$.

\section{Economic analysis}

We conducted a cost-utility analysis from a health care perspective, and compared the incremental cost and incremental utility gain of TFU in the intervention group compared to no TFU in the control group. The analysis relied on the QALYs gained over the six-month period derived from the social tariff [38].

\section{Ethics}

The study was approved by the Ethics Committee, Umeå University, Sweden (dnr 03-079).

\section{Result}

\section{Quality-adjusted life years}

At baseline, there were no significant differences in QALY score between intervention and control group. The intervention group also received a questionnaire after three months because we wanted to understand the lead period for the potential effect. We couldn't see the same reason for a 3 months measurement in the control group. Furthermore, even a questionnaire is a kind "light" intervention so they were excluded from the 3 month follow up. (Table 1). After six months, the QALY scores for interven- tion and control groups were 0.85 and 0.81 respectively ( $\mathrm{p}$ $=0.05$ ), with the greatest difference being seen among car occupants, who had scores of 0.87 and 0.79 respectively $(\mathrm{p}=0.01)$. If we assume that the difference in QALY scores developed linearly, the gain per person was 0.01 QALYs for the intervention group as a whole $(0.04 / 2$ multiplied by 0.5 years) and 0.02 QALYs for car occupants $(0.08 / 2$ multiplied by 0.5 years). In total, the intervention group gained 2.60 QALYs (0.01 each for 260 individuals). The car occupants gained 1.54 QALYs (0.02 each for 76 individuals). The total costs for the intervention group were 42500 SEK, and the intervention costs for the car occupant group were 13000 SEK. Thus the cost per QALY was 16000 overall and 8500 SEK for car occupants.

We undertook a simple sensitivity analysis based on the confidence intervals for costs and effects for the intervention group. For the entire intervention group, the ratio was between 9454 to 60644 SEK per QALY gained. In the car occupants group, the ratio was between 4284 and 13 798 SEK per QALY gained.

\section{Discussion and conclusion}

This study shows that nursing intervention via telephone follow up is cost effective when used alongside standard care in patients who were injured in the traffic environment, and that the costs per gained QALY are low; 16000 SEK overall and 8500 SEK among car occupants. The calculations presented show that the cost per QALY for nursing intervention via telephone follow-up is considerably

Table 3: Calculations of times and costs for the total intervention group and for the car occupants.

\begin{tabular}{|c|c|c|c|c|}
\hline \multicolumn{5}{|l|}{ Time } \\
\hline $\begin{array}{l}\text { Telephone calls } \\
\text { including before and } \\
\text { after work }\end{array}$ & $\begin{array}{l}\text { Intervention group } \\
(n=288)\end{array}$ & $\begin{array}{l}\text { Intervention car } \\
\text { occupants } \\
(n=87)\end{array}$ & $\begin{array}{l}\text { Intervention cyclists } \\
(n=99)\end{array}$ & $\begin{array}{l}\text { Intervention } \\
\text { pedestrians } \\
(n=102)\end{array}$ \\
\hline Total time & $\begin{array}{l}\text { I } 80 \text { hours } \\
\text { (4.5 weeks) }\end{array}$ & $\begin{array}{l}59 \text { hours } \\
\text { (1.4 weeks) }\end{array}$ & $\begin{array}{l}58 \text { hours } \\
\text { ( } 1.5 \text { weeks) }\end{array}$ & $\begin{array}{l}66 \text { hours } \\
\text { (1.6 weeks) }\end{array}$ \\
\hline \multicolumn{5}{|l|}{ Costs for the total time } \\
\hline Salary for the nurses & 38000 SEK & 12000 SEK & - & - \\
\hline Rent for premises & 4500 SEK & I 000 SEK & - & - \\
\hline Total & 42500 SEK & I 3000 SEK & - & - \\
\hline $\begin{array}{l}\text { Mean cost per } \\
\text { participant }\end{array}$ & |46 7| SEK & 13325 SEK & - & - \\
\hline (SD) & 42.21 & 33.97 & & \\
\hline $\begin{array}{l}\text { Confidence interval } \\
\text { (CI) }\end{array}$ & $|4| .82-|5| .6 \mid$ & $128.53-137.98$ & & \\
\hline
\end{tabular}


lower than the corresponding cost per QALY for the guiding principles from Swedish National Board of Health and Welfare, where low costs are defined as $<100000$ SEK per QALY, moderate costs as $\leq 500000$ SEK per QALY [39].

The strengths of this trial are the randomised controlled design and the large population. Moreover, the initial stratified sampling procedure made it possible to involve different types of road users, thus providing a good representation of the most injured road users in Sweden.

The time spent on each telephone call from the patient's perspective (for example, employment time) was not included in the calculations; however, most calls took place when the participants were at home. All direct costs caused by the nursing intervention via telephone followup were included, for example salary and rent for the premises. Because the evaluation focused on a narrow perspective, it was not able to evaluate the wider societal impact of the nurse intervention e.g. the impact on reducing work loss and productivity costs.

Although road traffic injuries constitute a major public health problem and impose large costs on society, economic evaluations concerning people injured in traffic incidents are scarce. The most similar patient groups represented in the literature are people with different kinds of neck complaints; the results of implementation studies are mixed. For example, Rosenfeld et al. [40], who studied people with whiplash injuries after traffic incidents, pointed out that the costs of interventions including information, postural control, and exercises were significantly lower after 6 and 36 months when compared with standard intervention, and the intervention group also showed significantly lower pain and less sick leave. On the other hand, Rebbeck et al. [41], who evaluated two implementation strategies for whiplash injury guidelines in physiotherapy, found that although the active implementation program increased guideline-consistent practice among the physiotherapists, the patient outcomes and cost of care were not affected. In a randomised trial, Lewis et al. [42] compared three different physiotherapy treatments for persons with non-specific neck disorders: advice and exercise plus manual therapy, advice and exercise plus pulsed shortwave diathermy, and advice and exercise alone. After six months, advice and exercise alone was the most cost-effective method and also that with the highest QALY scores. In summary, it seems that post-injury interventions which include advice provision are the most successful. In accordance with our results, advice seems to be a cost-effective method. One possible explanation for our results could be the dominance of minor injuries (MAIS 1 ) in the intervention group. Essentially, while in Sweden a follow-up visit will be booked for in principally all MAIS 2 injuries, such as fractures or other serious injures. This is not a routine for minor MAIS 1 injuries such as sprains or whiplash injuries.

Our results support that nursing intervention by telephone follow-up after an injury event is a very cost effective strategy giving an improved QALY to low cost, especially for those with minor injuries. Based on these results and noting that traffic injuries cause many subsequent problems for the injured parties, we recommend that health care providers consider implementing a nursing intervention program by telephone follow-up for all persons injured in the traffic environment.

\section{Competing interests}

The authors declare that they have no competing interests.

\section{Authors' contributions}

Study design: CF, LL; data collection: CF; data analysis: $\mathrm{CF}, \mathrm{UB}, \mathrm{CB}, \mathrm{LL}$; manuscript preparation: $\mathrm{CF}, \mathrm{UB}, \mathrm{CB}, \mathrm{LL}$.

\section{Acknowledgements}

This research was supported by the Swedish Association for Cancer and Traffic Victims.

\section{References}

I. Peden M, Scurfield R, Sleet D, Mohan D, Hyder A, Jarawan E, Mathers $C$ : The world report on road traffic injury prevention. WHO, Genewa; 2004.

2. Björnstig J, Bylund P-O, Björnstig U: Fordonsrelaterade skadefall som behandlats vid Norrlands Universitetssjukhus under 2005. Rapport 134. In Akut och katastrofmedicinskt centrum, Norrlands Universitetssjukhus, Umeå. (in Swedish) Accidents related to vechile, treated in Umeå University Hospital 2005. Report 134 Emergency and Disaster Medical Center Umeå, Sweden; 2006.

3. Jacobs G, Aeron-Thomas A, Astrop A: Estimating global road traffic fatalities. TRL. Report No. 445 Crowthorne, Transport Research Laboratory 2000.

4. Berntman M, Maraste P, Löfvendahl S, Persson U, Svensson M: Värdering av icke-dödliga skador till följd av trafikolyckor. Arbetsrapport 4: Skadade registrerade på Lunds sjukhus. Lunds Tekniska Högskola. In Institutionen för Teknik och samhälle, Avdelning Trafikteknik. (in Swedish). Estimation of costs for non fatally traffic injuries. Workreport 4. Injured registred at the Lund Hospital, Sweden Department of Technology and Society. Lund Institute of Technology, Traffic Engineering, Lund, Sweden; 1999.

5. Maraste P, Persson U, Berntman M: Long-term follow-up and consequences for severe road traffic injuries-treatment costs and health impairment in Sweden in the 1960s and the 1990s. Health Policy 2003, 66:147-I58.

6. Persson U, Hjalte $\mathrm{K}$, Nilsson $\mathrm{K}$, Norinder A: The value of reducing the risk for traffic accidents-Estimates valuation, willingness to pay, value of a statistical life, value of risk reduction In Bulletin 183. Department of Technology and Society. Lund Institute of Technology, Traffic Engineering, Lund, Sweden; 2000.

7. Franzén C, Björnstig U, Jansson L, Stenlund H, Brulin C: Injured road users' experience of care in the Emergency Department. Journal of Clinical Nursing 2008, I 7:726-734.

8. Cedergren L, Bylund E: Trafikskadades synpunkter på omhändertagandet vid Norrlands Universitetssjukhus, Umeå. Rapport I I 2. In Akut och katastrofmedicinskt centrum, Norrlands Universitetssjukhus, Umeå. (in Swedish) Traffic injured's experiences of caring in Umeå University Hospital. Report I I 2 Emergency and Disaster Medical Center Umeå, Sweden; 2002.

9. Albertsson P, Björnstig U: Busskraschen vid Granån 200I-med 34 skadade. Rapport I I 6. In Akut och Katastrofmedicinskt Centrum, Norrlands Universitetssjukhus, Umeå. (in Swedish). Bus crash Granån 
200 I-with 34 injured persons. Report I / 6 Emergency and Disaster Medical Center Umeå, Sweden; 2003.

10. Franzén C, Björnstig U, Jansson L: Injured in traffic: Experiences of care and rehabilitation. Accident and Emergency Nursing 2006, 14:104-II0.

II. Andersson A-L: Psychosocial factors and traffic injuries. With special emphasis on consequences, risk factors for complications, influence of alcohol and benefits of intervention. Department of Orthopaedics, Institute of Surgical Sciences, Göteborgs University, Göteborg, Sweden; 2003.

12. Mayou R, Bryant B: Outcome in consecutive emergency department attenders following a road traffic accident. British Journal of Psychiatry 200I, 179:528-534.

13. Wang C-H, Tsay S-L, Bond A: Post-traumatic stress disorder, depression, anxiety and quality of life in patients with trafficrelated injuries. Journal of Advanced Nursing 2005, 52:22-30.

14. Andersson A-L, Dahlbäck L-O, Bunketorp O: Psychosocial aspects of road traffic trauma-benefits of an early intervention? Injury 2005, 36:917-926.

15. Li L, Roberts I, Power C: Physical and psychological effects of injury. Data from the 1958 British birth cohort study. European Journal of Public Health 200I, I I:8I-83.

16. Richmond T, Thompson H, Deatrick J, Kauder D: Journey towards recovery following physical trauma. Journal of Advanced Nursing 2000, 32: $134 \mid-1347$.

17. Harms L: After the accident: Survivors' perceptions of recovery following road trauma. Australian Social Work 2004, 57:161-174.

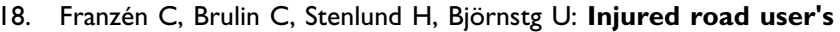
health-related quakity of life after telephone intervention: a randomised controlled trial. Accepted in Journal of Clinical Nursing 2008.

19. American College of Surgeons \& Trauma: Advanced trauma life support program 4 edition. American College of Surgerons, Chicago; 2004.

20. Emergency, Nursing \& Association: Trauma Nursing Core Course. 4th edition. ENA Emergency Nurses Association, Des Plaines IL; 2000.

2I. Taylor RS, Watt A, Dalal HM, Evans PH, Campbell JL, Read KL, Mourant AJ, Wingham J, Thompson DR, Pereira Gray DJ: Home-based cardiac rehabilitation versus hospital-based rehabilitation: a cost effectiveness analysis. International Journal of Cardiology 2007 I I 9: 196-20I.

22. Jolly K, Taylor RS, Lip GY, Greenfield S, Raftery J, Mant J, Lane D, Jones M, Lee KW, Stevens A: The Birmingham Rehabilitation Uptake maximisation Study (BRUM). Home-based compared with hospital-based cardiac rehabilitation in a multiethnic population: cost effectiveness and patient adherence. Health Technology Assesment 2007, I I:I-I I 8.

23. Dunagan WC, Littenberg B, Ewald GA, Jones CA, Emery VB, Waterman BM, Silverman DC, Rogers JG: Randomized trial of a nurseadministered, telephone-based disease management program for patients with heart failure. Journal of Cardiac Failure 2005, I I:358-365.

24. Beaucage K, Lachance-Demers H, Ngo TT, Vachon C, Lamarre D, Guevin J, Martineau A, Desroches D, Brassard J, Lalonde L: Telephone follow-up of patients receiving antibiotic prescriptions from community pharmacies. America Journal of Health-System Pharmacy 2006, 63:557-563.

25. Steel O'Connor KO, Mowat DL, Scott HM, Carr PA, Dorland JL, Young Tai KFW: A randomized trial of two public health nurse follow-up programs after early obstetrical discharge. An examination of breastfeeding rates, maternal confidence and utilization and costs of health services. Canadian Journal of Public Health 2003, 94:98-103.

26. Simon GE, Von Korff M, Rutter C, Wagner E: Randomised trial of monitoring, feedback and management of care by telephone to improve treatment of depression in primary care. British Medical Journal 2000, 320:550-554.

27. Richards DA, Meakins J, Tawfik J, Godfrey L, Dutton E, Richardson G, Russell $D$ : Nurse telephone triage for same day appointments in general practice: multiple interrupted time series trial effects on workload and costs. British Medical Journal 2002, 325: $1214-1217$.

28. Pinnock H, Mckenzie L, Price D, Sheikh A: Cost-effectiveness of telephone or surgery asthma reviews: economic analysis of a randomised controlled trial. British Journal of General Practice 2005, 55: II9-124.

29. Anari S, Arullendran P, Reilly J: How we do it: Cost-benefit analysis of implementing a telephone review system in an ENT outpatient setting. Journal of Clinical Otolaryngology 2006, 3I:32I-338.

30. Elliot RA, Barber N, Clifford S, Horne R, Hartley E: The cost effectiveness of a telephone-based pharmacy advisory service to improve adherence to newly prescribed medicines. Journal of the Pharmacy World Sciences 2008, 30:17-23.

31. Association, et al:: The Abbreviated Injury Scale 1990 revision. Update 98. AAAM, Des Plaines, IL; 1998.

32. EuroQolGroup: EuroQol-A new facility for the measurement of health related quality of life. Health Policy 1990, 16:199-208.

33. Brooks R: EuroQol: The current state of play. Health Policy 1996, 37:53-72.

34. Rabin R, de Charro F: EQ-5D: A measure of health status from the EuroQol group. Annals of Medicine 200I, 33:337-343.

35. Torrance G: Measurements of health states utilities for economic appraisal: a review. Journal of Health Economics 1986, 5:I-30.

36. Drummond M, O'Brien B, Stoddart G, Torrance G: Methods for the economic evaluation of health care programmes. 2nd edition. Oxford university press, New York; 1997.

37. Dolan P: Modeling valuations for EuroQol health states. Medical Care 1997, 35: 1095- I 08.

38. Dolan P, Gudex C, Kind P, Williams A: A social tariff forEeuroQol: Results from a UK general populations survey. Center for Health Economics, University of York, United Kingdom; 1995.

39. Socialstyrelsen: Nationella riktlinjer för vård, behandling och omsorg. In Stockholm. Nationella riktlinjer for vård behandling och omsorg. Stockholm. (in Swedish) National principles for caring and treatment Swedish National Board of Health and Welfare; 2008.

40. Rosenfeld M, Seferiadis A, Gunnarsson R: Active involvement and intervention in patients exposed to whiplash trauma in automobile crashes reduces costs. Spine 2006, 31 : 1799-1804.

4I. Rebbeck T, Maher CG, Refshauge KM: Evaluating two implementation strategies for whiplash guidelines in physiotherapy: A cluster-randomised trial. Australian Journal of Physiotherapy 2006, 52:165-174.

42. Lewis M, James M, Stokes E, Hill J, Sim J, hay E, Dziedzic K: An economic evaluation of three physiotherapy treatments for non-specific neck disorders alongside a randomized trial. Journal of Rheumatology 2007, 46:1701-1708.

\section{Pre-publication history}

The pre-publication history for this paper can be accessed here:

\section{http://www.biomedcentral.com/1472-6963/9/98/prepub}

Publish with Biomed Central and every scientist can read your work free of charge

"BioMed Central will be the most significant development for disseminating the results of biomedical research in our lifetime."

Sir Paul Nurse, Cancer Research UK

Your research papers will be:

- available free of charge to the entire biomedical community

- peer reviewed and published immediately upon acceptance

- cited in PubMed and archived on PubMed Central

- yours - you keep the copyright 